\title{
Making Banks Safer: \\ Can Volcker and Vickers Do It?
}

Julian T.S. Chow and Jay Surti 


\title{
IMF Working Paper
}

Monetary and Capital Markets Department

\section{Making Banks Safer: Can Volcker and Vickers Do It? ${ }^{1}$ \\ Prepared by Julian T. S. Chow and Jay Surti}

Authorized for distribution by Aditya Narain

November 2011

\begin{abstract}
This paper assesses proposals to redefine the scope of activities of systemically important financial institutions. Alongside reform of prudential regulation and oversight, these have been offered as solutions to the too-important-to-fail problem. It is argued that while the more radical of these proposals such as narrow utility banking do not adequately address key policy objectives, two concrete policy measures - the Volcker Rule in the United States and retail ring-fencing in the United Kingdom - are more promising while still entailing significant implementation challenges. A risk factor common to all the measures is the potential for activities identified as too risky for retail banks to migrate to the unregulated parts of the financial system. Since this could lead to accumulation of systemic risk if left unchecked, it appears unlikely that any structural engineering will lessen the policing burden on prudential authorities and on the banks.
\end{abstract}

JEL Classification Numbers: G21, G24, G32, G38

Keywords: Banks, Business Models, Systemic Risk

Authors’ E-Mail Addresses: jchow@imf.org and jsurti@imf.org

\section{This Working Paper should not be reported as representing the views of the IMF.}

The views expressed in this Working Paper are those of the author(s) and do not necessarily represent those of the IMF or IMF policy. Working Papers describe research in progress by the author(s) and are published to elicit comments and to further debate.

\footnotetext{
${ }^{1}$ The authors are grateful to Ashok Bhatia, Phil de Imus, Aditya Narain, İnci Ötker-Robe, Zoltan Pozsar, and Constant Verkoren for comments on earlier drafts. The usual disclaimer applies.
} 


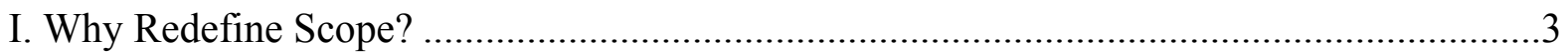

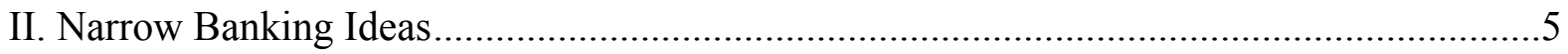

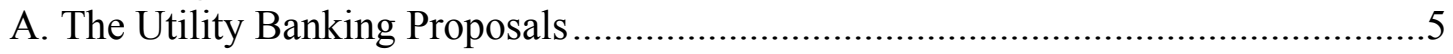

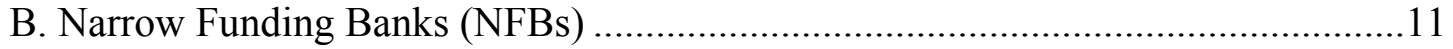

III. Full Institutional Separation of Functions: the Volcker Rule .........................................13

A. Rationale for the Rule ................................................................................. 13

B. What Businesses Must Commercial Banks Give Up? .......................................... 17

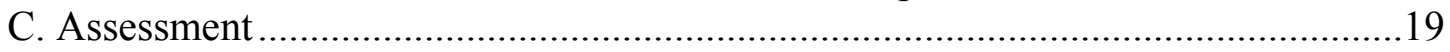

IV. Functional Subsidiarization: Retail Ring-Fencing......................................................22

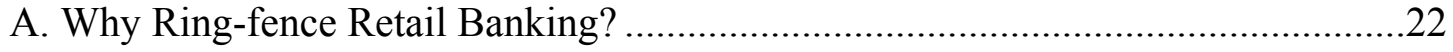

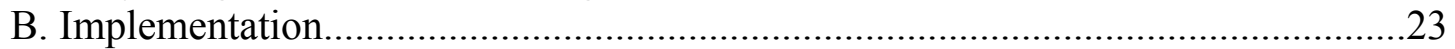

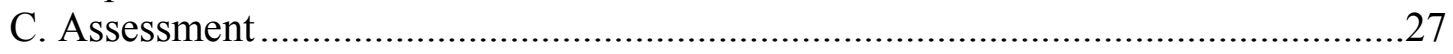

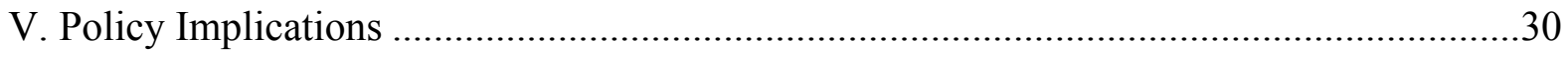

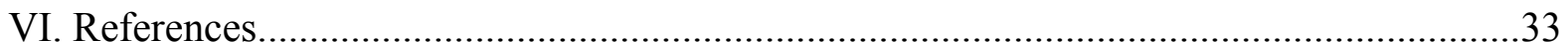

Tables

1. Utility Banking Proposals .........................................................................................

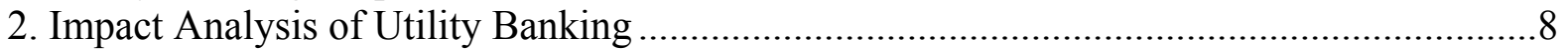

3. Results for U.S., European, and Asian LCFIs ...................................................... 15

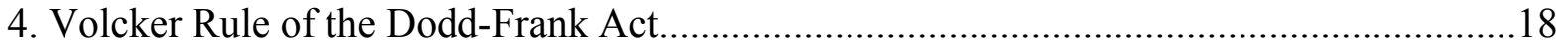

5. Quantitative Metrics Proposed by FSOC ...................................................................21

6. Capital Constraints for Ring-fenced Banks ................................................................26

7. Comparing the Volcker Rule and the ICB Ring-fencing Proposals ................................29

Figures

1. Transformation of Universal Banking into Utility Banking ........................................6

2. Rescoping of Banks’ Businesses Under the Volcker Rule ..............................................17

3. Rescoping of Bank's Businesses Undwer the ICB Ring-fence .....................................27

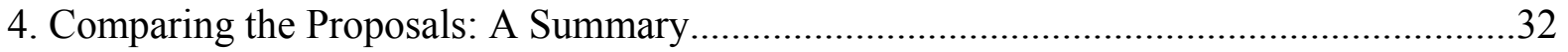

Box 1. Do Trading Activities Increase the Vulnerability of Banks? ..................................14 


\section{WHY REDEFINE SCOPE?}

The business of banking involves leveraged intermediation managed by people subject to limited liability and, typically, to profit sharing contracts. This combination is well-known to generate incentives for risk-taking that may be excessive from the perspective of bank creditors. Creditor guarantees such as deposit insurance are known to exacerbate this incentive problem because they weaken creditors' incentive to monitor and discipline management.

These issues are magnified in the case of systemically important financial institutions (SIFIs). Owing to their size, interconnectedness, or complexity, the negative externalities emanating from financial distress at SIFIs makes them a source of systemic risk, leading to them being perceived to be too-important-to-fail (TITF). Consequently, the market implicitly — and often correctly — assumes that apart from explicit deposit insurance, creditor guarantees of a much wider nature would be extended when such firms are threatened by imminent failure.

This serves to weaken the mitigating force of market discipline. Prior to the crisis, the high likelihood of public support assumed in a distress situation contributed to the ability of SIFIs to carry thinner capital buffers at lower cost, acquire complex business models, and accumulate systemic risk. This trend was reinforced by the diversification premium attributed to universal banks by market participants and prudential authorities, enabling them to integrate the provision of retail, investment, and wholesale banking services without erecting the necessary firewalls there-between. These developments resulted in networks of financial interconnections within and across internationally active SIFIs that proved to be difficult, time consuming and costly to unravel. This made it seemingly less costly, during the crisis, to allocate tax payer resources to preventing SIFI failures than to allowing them, with subsequent resolution and restructuring of their businesses.

Diversification of business lines could serve to better protect a universal bank against idiosyncratic shocks that adversely impact individual lines of business. At the same time, the free flow of capital and liquidity and the associated growth in intra-group exposures would also increase the likelihood of intra-firm contagion in the event of an exogenous shock. Unlike investment banking clients, retail banking customers typically have few options other than their banks for conducting vital financial transactions. Ensuring business continuity of services to such clients, therefore, serves a clear and important social welfare objective. But, complex business models and high levels of intra-group exposures present a barrier to quickly spinning off the retail parts of a universal bank which can ensure such business continuity.

Restricting the scope of a regulated bank's business activities could, therefore, serve a number of important policy objectives. From a financial stability perspective, it could limit contagion within and across firms. From the perspective of consumer protection, it could 
ensure a more efficient provision of assurance of the continuity of retail banking services. And, by more credibly restricting the ambit of tax-payer funded creditor guarantees to depositors it could furnish these benefits more efficiently and cheaply from a social cost perspective.

Accordingly, the official response to the crisis has, besides recognizing the need for strengthened regulation and oversight of SIFIs, also included complementary proposals to redesign and refocus their business activities. A number of concrete proposals have been made, including:

- Narrow Utility Banking - essentially a reversion of deposit-funded banks into traditional payment function outfits with lending (and investment banking) being carried out by independent finance companies funded by non-deposit means.

- The Volcker Rule - prohibiting banks from carrying out certain types of investment banking activities if they are to continue to seek deposit funding and to retain banking licenses.

- A Retail Ring-fence - that, while not prohibiting banking groups from providing both retail and wholesale banking services, mandates legal subsidiarization of certain retail activities, prohibits this subsidiary from undertaking other businesses and risks, and establishes minimum capital and liquidity standards for it on a solo basis. While not limiting capital and liquidity benefits to the retail subsidiary from other affiliates when necessary, the ring-fence limits capital and liquidity transfers in the opposite direction, to non-ring-fenced affiliates. Such functional subsidiarization could enable continuation of retail operations under distress or failure of a SIFI's other businesses.

This paper focuses on the motivation, content, operational challenges, and potential costs of these proposals to narrow the scope of banking business. The more radical proposals discussed under the narrow banking umbrella involve strict limits on what retail banks' permissible activities ought to be and could entail significant dead-weight costs if implemented as recommended. By contrast, the design and motivation for the Volcker rule and retail ring-fence are more precisely targeted at the problems arising from the integrated business models used by SIFIs before the crisis.

The challenge facing these latter proposals lies in the feasibility and cost of their implementation. In the case of the Volcker rule, for example, it will be challenging for prudential authorities to tell apart permissible activities (market making and underwriting) from prohibited ones (proprietary trading) when assessing banks' exposures to securities markets. Similar difficulties will be faced by supervisors assessing the nature of and purpose of hedging tools and contracts utilized by ring-fenced banks. This presents policy makers with a dilemma. Should they invest the financial cost and time towards gathering more contemporaneous information in order to create better filters and limit loopholes? Or, if this 
is viewed as being too costly or simply inefficient, should they move to outright prohibition of all activities related to securities markets?

The danger with the second option lies in generating incentives to push risk taking beyond the borders of the regulated financial system. If there are indeed no direct financial linkages between retail financial firms and such shadow banking entities, such risk taking may cease being a problem of regulation. However, systemic risk will continue to accumulate in the shadow banks, and since the participants in the regulated and shadow systems are the same, or are, in general linked, a crisis in that sector will continue to exercise a contagion impact on the regulated banking sector.

Sections II, III, and IV respectively discuss the narrow banking, Volcker rule, and retail ringfence proposals. Section V concludes with some reflections on policy implications.

\section{NARROW BANKING IDEAS}

\section{A. The Utility Banking Proposals}

Utility banking proposals seek to define institutional and regulatory boundaries along functional lines, distinguishing — somewhat arbitrarily_-'non-risky' utility banking services from 'risky' non-utility activities. The available literature does not make the idea of utility banking precise, but presumably inclusion is limited to those services that facilitate real sector activity and (sustainable) economic growth.

In the aftermath of the global financial crisis, utility banking proponents have emphasized the need for lowering asset-liability mismatches and leverage risks via drastic restrictions on what lines of business regulated, deposit-funded banks can pursue (Figure 1 and Table 1). The most radical of these proposals envisage institutional separation between banks serving payments function needs and companies engaged in commercial lending and other activities. Utility banks are envisaged as licensed, regulated, deposit-funded entities, constrained to invest in high credit quality, liquid securities, and would alone qualify for public creditor guarantees where these are extended. Lending, where permitted is restricted to a few sectors such as consumer and mortgage credit, whereas the majority of commercial lending and investment banking is carried out by legally separate finance companies funded by debt and equity. ${ }^{2}$ Holding company structures wherein both types of institutions can coexist as

\footnotetext{
${ }^{2}$ Lending activity is never risk-free. The important issue, however, is not the presence of risk per se as the incentives for proper under-writing of this risk. Incentives for quality underwriting are generally more likely to be preserved when banks' bottom-lines depend upon good loan performance. On the other hand, the ability to pad such transactions with excessive leverage obtained at low cost may yield levels of risk that are prohibitively costly for tax payers to back-stop. The experience with subprime mortgage lending in the United States prior to the financial crisis suggests that complementary reform measures - that are in train —on the regulation of securitized lending may be necessary to make banks safer through the rescoping of their business lines.
} 
subsidiaries are permitted, albeit legal, financial, and managerial separation is strictly enforced.

Figure 1. Transformation of Universal Banking into Utility Banking

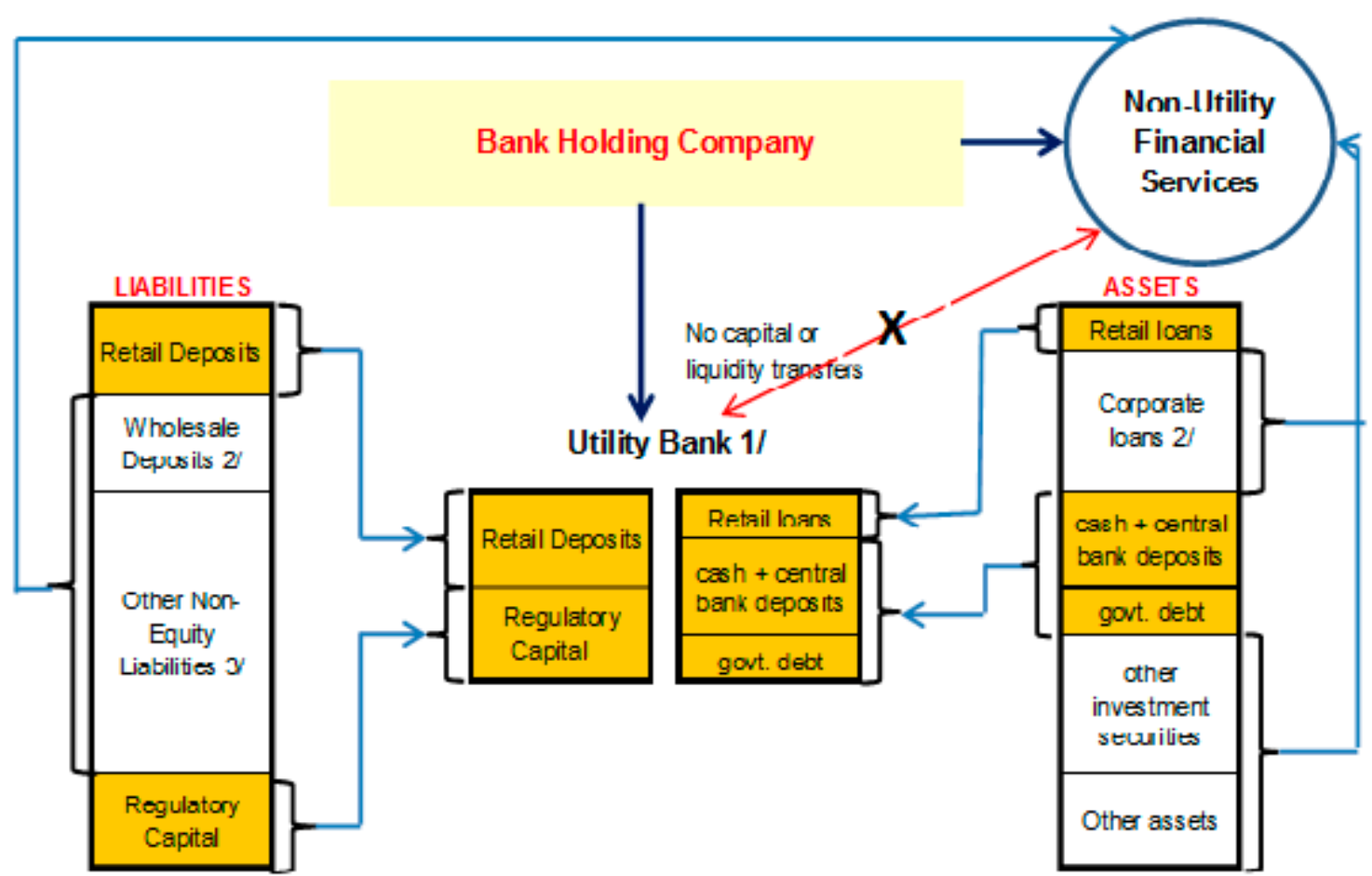

Notes:

1/ Besides the rescoping of business represented by balance-sheet adjustments, also entails prohibition on provision of a number of financial services (e.g., trading of securities on own account and investment banking services such as prime brokerage, market making, and underwriting, among others).

2/ Includes interbank exposures.

3/ Includes funding vehicles such as asset backed commercial paper, repo/securities lending, among others. 
Table 1. Utility Banking Proposals

\begin{tabular}{|c|c|c|c|}
\hline & Payment Function vs. Lending & Permissible Corporate Structure & Regulation and Public Guarantees \\
\hline $\begin{array}{l}\text { Litan (1987), } \\
\text { Pierce (1991) }\end{array}$ & $\begin{array}{l}\text { Deposit funded banks solely } \\
\text { perform a payments function, } \\
\text { invest only in high (credit) quality, } \\
\text { short-term / liquid assets. } \\
\text { Lending is undertaken by } \\
\text { independent finance companies } \\
\text { that fund themselves using a } \\
\text { combination of equity and non- } \\
\text { deposit debt instruments. }\end{array}$ & $\begin{array}{l}\text { Holding company structures that } \\
\text { co-own banks and finance } \\
\text { companies are permitted. Strict } \\
\text { firewalls are required between } \\
\text { individual business units / lines; } \\
\text { i.e., financial interconnections } \\
\text { between bank and finance } \\
\text { company affiliates are prohibited. }\end{array}$ & $\begin{array}{l}\text { Banks alone are subject to licensing } \\
\text { and regulatory oversight and have a } \\
\text { capital base. Public guarantees } \\
\text { (deposit insurance) only given to } \\
\text { deposit funded banks. Equity and } \\
\text { debt holders of finance companies } \\
\text { fully bear any losses ensuing from } \\
\text { insolvency of finance companies. }\end{array}$ \\
\hline $\begin{array}{l}\text { Bryan (1991), } \\
\text { Kay (2009) }\end{array}$ & $\begin{array}{l}\text { Litan and Pierce plus a bank can } \\
\text { extend credit to retail and } \\
\text { mortgage borrowers. Other } \\
\text { lending services are provided by } \\
\text { separate lending subsidiary. } \\
\text { Securities issuance and trading } \\
\text { is not permitted. }\end{array}$ & Same as above. & Same as above. \\
\hline $\begin{array}{l}\text { Kashyap et. } \\
\text { al. (2002) }\end{array}$ & $\begin{array}{l}\text { Banks issue both, insured narrow- } \\
\text { bank deposits collateralized by } \\
\text { high-grade securities and } \\
\text { uninsured deposits to finance } \\
\text { private sector lending. }\end{array}$ & Same as above. & Same as above. \\
\hline
\end{tabular}

Sources: Litan (1987), Bryan (1991), Pierce (1991), Kashyap et. al. (2002), and Kay (2009).

To the extent that practical implementation of the utility banking proposals yields an accurate functional separation of utility from non-utility activities, a number of benefits could ensue to the economy and the financial system. ${ }^{3}$ Leverage in deposit funded institutions would be lowered by jettisoning investment banking activities such as trading, investment funds, and securitization. Asset-liability matching would be enhanced by restricting the class of permissible assets to liquid, high credit quality securities. Restricting access to the payments system to narrow banks would isolate the systemic risk of losses at non-utility finance companies, thus protecting banks from credit, liquidity and settlement risks. Finally, the restriction of public creditor guarantees to utility banks alone would sharpen creditor incentives in monitoring manager-owners of non-utility institutions. In theory, this would alleviate the moral hazard problem and lessen the pressure on supervisory agencies. Measured against a set of criteria ranging from macro-financial stability to financial costs, the economic impact of utility banking would be substantial (Table 2).

\footnotetext{
${ }^{3}$ With the separation of utility and non-utility banks, the choice of 'portfolio allocation' rests with the individual investor/depositor. A more risk-averse individual may choose to deposit his/her savings fully in utility banks at a lower deposit rate in return for safety. Conversely, a less risk-averse individual may reduce the extent of deposits with utility banks in favor of potentially higher returns from investment in equities/debentures issued by non-utility financial affiliates, albeit at a higher risk profile.
} 
Table 2. Impact Analysis of Utility Banking

\begin{tabular}{|c|c|}
\hline Financial System and Economy & Banks \\
\hline \multicolumn{2}{|c|}{ Stability } \\
\hline $\begin{array}{l}\text { Banking stability may be strengthened by the } \\
\text { detachment of high leverage investment } \\
\text { banking, trading business, and associated } \\
\text { asset liability mismatches. } \\
\text { However, the shift of lending and investment } \\
\text { banking to an unregulated or } \\
\text { weakly/differently regulated shadow sector } \\
\text { could transfer systemic risk to non-banks. To } \\
\text { the extent that this sector funds a non-trivial } \\
\text { proportion of real sector activities- } \\
\text { particularly using retail savings-this would } \\
\text { directly reduce the stability benefits of the } \\
\text { proposal. }\end{array}$ & $\begin{array}{l}\text { - Narrower structures, and the firewalls } \\
\text { envisaged between banks and finance } \\
\text { companies, can be expected to increase } \\
\text { resilience of regulated banks to unanticipated } \\
\text { shocks. This would, among other things, } \\
\text { facilitate a spinning-off of healthy utility banks } \\
\text { by resolution authorities, thereby enabling } \\
\text { better management of institutional distress. } \\
\text { - } \text { Consequently, utility banking facilitates the } \\
\text { effective implementation of bank resolution. } \\
\text { However, breaking-up banks could also lead to } \\
\text { a loss of diversification benefits especially when } \\
\text { correlations between risks from different lines of } \\
\text { business are low during normal times. }\end{array}$ \\
\hline \multicolumn{2}{|c|}{ Cost } \\
\hline $\begin{array}{l}\text { - Adverse effects on consumers may include } \\
\text { lower deposit returns and a reduction in utility } \\
\text { from the absence of a "one-stop" centre for } \\
\text { all banking needs. } \\
\text { - Where lending is transferred to non-bank } \\
\text { finance companies, average credit costs in } \\
\text { the economy may increase or credit supply } \\
\text { decrease as a result of the absence of public } \\
\text { creditor protection. While in certain segments } \\
\text { (e.g., subprime or low documentation } \\
\text { housing finance), this would lead to costs } \\
\text { moving up to better reflect credit risk, in other } \\
\text { segments (e.g., small and medium enterprise } \\
\text { loans or prime credit cards or prime auto } \\
\text { loans), the increase in cost or tightening in } \\
\text { supply could represent an unintended } \\
\text { negative externality. }\end{array}$ & $\begin{array}{l}\text { For universal banks, higher costs may derive } \\
\text { from: } \\
\text { - Adjustment, as established contracts are } \\
\text { difficult to unwind and the restructuring may } \\
\text { be costly. } \\
\text { - Higher operational costs, as tax benefits of } \\
\text { combining operations under one corporate } \\
\text { body may be lost together with cost savings } \\
\text { in a single back-office operations platform. } \\
\text { Overall funding cost for bank holding } \\
\text { companies (BHCs) combining utility } \\
\text { banking with lending activity will be higher } \\
\text { as the separation of utility and non-utility } \\
\text { banks cuts (publicly guaranteed) deposit } \\
\text { funding for non-bank finance companies } \\
\text { and natural hedges across business lines } \\
\text { are no longer available. }\end{array}$ \\
\hline \multicolumn{2}{|c|}{ Efficiency } \\
\hline $\begin{array}{l}\text { - Competition would drive improvements in } \\
\text { core banking services, thus enhancing the } \\
\text { quality and range of services, and benefitting } \\
\text { the society at large. }\end{array}$ & $\begin{array}{l}\text { - Efficiency of banks could be enhanced as they } \\
\text { focus on core banking activities such as } \\
\text { maturity transformation and provision of } \\
\text { payments services. } \\
\text { - The economic effects of signaling may also } \\
\text { benefit BHCs as simpler, segregated structures } \\
\text { which manage risk better may lead to gains in } \\
\text { reputation and franchise value. }\end{array}$ \\
\hline
\end{tabular}




\section{Separation of lending from deposit taking may impose significant social cost}

The rationale for the institutional separation implied by utility banking appears to arise from the observation that the coexistence of lending based on risky leverage and asset-liability maturity mismatches with deposit-funding translates into an increase in contagion risk to traditional banking and worsens the moral hazard problem. It seems to provide support to market assumptions that the boundary of public creditor protection is flexible beyond deposits. In turn, this leads to weaker market discipline which promotes the further accumulation of systemic risk.

Even if one were to grant the foregoing hypothesis, the implication that there should be complete institutional separation of deposit funding and payments system access from all credit intermediation remains elusive. Maturity transformation financed by deposit-based leverage is the traditional business of commercial banks in the same manner as (re)discounting of securities and managing payments between clients and to other banks. Asset securitization - especially of subprime mortgages, of mortgage-backed securities and of their derivatives - resulted in borrowing costs that may not have reflected underlying borrower credit risk and encouraged very high levels of leverage in the financial system. But, incentives to maintain tighter underwriting standards and higher capital buffers for loans that remain on banks' balance-sheets are substantially stronger.

In other words, it is difficult to make a case based on events leading up to the crisis for banks to give up deposit-based funding of loans. This fact becomes more apparent when, while considering the scope of a bank's utility enhancing activities, one considers the informational advantage of banks in overcoming adverse selection in the lending process (relationship lending). Moreover, there is synergy between deposit-taking and lending activities when they are viewed as alternative, imperfectly correlated manifestations of liquidity provision by banks, which gives rise to efficiencies in the joint provision of these services using a single balance-sheet. ${ }^{4}$

\section{Successful implementation requires overcoming significant operational challenges}

A number of operational challenges related to preventing regulatory arbitrage appear to limit the scope for utility banking in practice.

- Cross-border regulatory arbitrage may thwart national utility banking reform. The proposal needs consistent application across jurisdictions to be effective. Even if regulators could successfully prescribe a list of non-utility banking activities,

\footnotetext{
${ }^{4}$ Kashyap et. al. (2002) demonstrate using both theoretical and empirical analyses that imperfect correlation between the demand for liquidity by depositors and borrowers lowers the cost of joint provision of both services relative to separate institutional provision.
} 
harmonization of regulatory regimes in different countries may be a challenge due to differences in the level and pace of financial development. Absent such coordination, however, universal banks could relocate their listing status to jurisdictions with less strict regulations, thus leaving the TITF problem unaddressed.

- Utility banks may constrain moral hazard of bank management but investor temptation to take risk remains and can result in accumulation of systemic risk outside of the regulated banking system. Utility banks would appeal to depositors during times of financial distress as they are protected but the lure of higher returns during normal economic times may prompt savers to put their money with shadow banks which are beyond the boundary of government regulation. This would reduce the role of utility banks in periods of prolonged moderation, thereby shifting risk to shadow banks in such magnitude that, when another crisis hits, the losses are high enough to warrant the use of public funds to rescue failing shadow banking entities.

- Narrowing the perimeter of regulation need not follow from utility banking. An argument that is often made in favor of utility banking in existing studies is the potential relaxation of inefficient regulation and intrusive supervisory constraints which also has the added benefit of lowering the social cost of policing banks. However, since systemic risk can still build up through shadow banks, affecting retail investors and the real economy, the case of extending the regulatory perimeter around these institutions remains despite the transition to utility banking.

- Utility banking will not eliminate market risk. While the default risk on a 10 -year U.S. Treasury note may be very low, a steepening of the treasury curve would result in large mark-to-market losses for deposit-funded banks. Therefore, caps on the duration of tradable fixed income securities will be necessary so as to minimize market risk. Alternatively, the universe of eligible assets for utility banks will need to be further restricted to variable interest securities or short-term notes.

\section{Adjustment costs could be significant}

Adjustment costs related to unwinding and decoupling integrated businesses are likely to be high. The proposal could be particularly costly in Europe where the universal banking business model is more widely prevalent. Moreover, implementing the proposal in countries with underdeveloped financial sectors may be infeasible because of the paucity of high credit quality, liquid securities.

- Unwinding a complex universal bank is a costly and time consuming process. This is especially so in the case of European TITF institutions which are predominantly universal banks. Interlinkages between various parts of a bank holding company (BHC) may be difficult to unwind, let alone for the entire organization to be restructured. For instance, 
structured finance may involve deposit funding coupled with derivatives structured internally by structuring desks, which in turn is 'manufactured' and hedged by trading desks. The hedging of these derivatives may be done with an external counterparty or another internal unit within the bank which makes it difficult to 'unbundle' the complicated relationships.

- Utility banking presents implementation challenges for emerging markets and low income countries as well. It presumes deep and liquid secondary markets for government and private debt securities. Moreover, the funding needs of finance companies in many of these countries largely hinges on domestic capital markets, without which the functioning of credit intermediation would be severely disrupted.

\section{B. Narrow Funding Banks (NFBs)}

\section{The proposal}

The fundamental goal behind the NFB proposal put forward by Gorton and Metrick (2010) is to bring securitization within the regulatory perimeter, by housing the purchase of assetbacked securities (ABS) within licensed and regulated institutions.

Under the proposal, NFBs are envisioned to be chartered institutions subject to prudential requirements associated with ceilings on leverage, market, and liquidity risk; restrictions on eligible assets collateralizing the purchased ABS as well as on portfolio quality and concentration. ${ }^{5}$ NFBs would be subjected to periodic examinations and would gain access to the central bank's discount window facilities. ${ }^{6}$

(Equity) capital would be raised through issuance of medium-term notes (MTNs) with scheduled maturity points which are extendible in the event that the institution has breached regulatory capital requirements at the time of maturity. Instead, the company would switch to a no growth mode or a natural amortization mode, wherein risk reduction would be undertaken through rebuilding of the capital base via prohibition on dividend payouts to equity holders (no growth) and in addition to the fund managers (natural amortization). Capital, therefore, takes on a debt-like structure during normal times and reverts to equitylike during times of stress. Non-equity funding would be raised through non-deposit means via issuance of commercial paper, MTNs and bonds, and through repos. NFBs are viewed as

\footnotetext{
${ }^{5}$ Constraints on portfolio quality are measured by the minimum proportions of assets to be held above given ratings thresholds.

${ }^{6}$ The proposal, as originally constructed, was applied to NFBs chartered in the United States under the regulatory and supervisory purview of the Federal Reserve Banks, and eligible for the Fed's discount window facility.
} 
engaged in a pure spread business, and would be barred from making loans or exposing ownfunds to proprietary trading and derivatives businesses. ${ }^{7}$ Their sole business activity would be to purchase ABS, though they would be allowed to invest in other high-grade assets and treasury securities presumably for liquidity management purposes.

In terms of legal and economic organization, NFBs would be structured as standalone, separately ring-fenced legal entities with no direct cross-ownership linkages to commercial banks. Taken together with prudential requirements described above, this is seen as promoting more efficient bank recovery and resolution.

\section{Assessment}

Independent, regulated, and separately capitalized securitization firms would promote ringfencing of regulated banks' retail operations in times of stress. Moreover, the conversion of (part of) NFB debt into equity during times of stress may provide stronger market incentives to limit borrower leverage in the housing market. However, credit risk may become more concentrated in NFBs, and other incentive problems with the pre-crisis securitization model still remain and must be directly addressed through complementary measures.

- Concentration Risk: As NFBs assume the function of ABS conduits and SIVs from banks, the concentration of securitization risk may render them vulnerable during times of deteriorating credit conditions. Though access to the Fed's discount window may alleviate short term liquidity problems, solvency risk continues to depend on the performance of the credits underlying the ABS portfolio.

- Resolving Incentive Problems Embedded in the Originate-to-Distribute Securitization Model: More fundamentally, therefore, chartering of NFBs under the specified prudential constraints will not be sufficient by itself to remedy the incentive problems with the precrisis originate-to-distribute model of securitization. NFBs do not address incentive problems related to the quality of loan underwriting arising from low credit risk retention by originators and securitization deal sponsors. Similarly, the NFB proposal is not designed to, and therefore, will not address coordination problems arising from conflicts of interest between senior and junior lien holders of the assets collateralizing the ABS. Finally, changes to originator-servicers', mortgage bonds trustees', and underwriters' remuneration contracts and to securitization waterfall structures are necessary complements to chartering of NFBs. Without such changes, it is difficult to foresee the mere introduction of NFBs as sufficient to reduce either, the scope for misrepresentations by originators and underwriters or the scope for mortgage defaults and foreclosures and the associated potential dead-weight costs incurred during macro-financial dislocations.

\footnotetext{
${ }^{7}$ NFBs can undertake repo transactions with private investors and entities with full disclosure of risk.
} 


\section{Full Institutional Separation of Functions: the Volcker RULE}

\section{A. Rationale for the Rule}

The Volcker Rule of the Dodd-Frank Act in the United States (U.S.) separates some investment banking activities from commercial banking. The motivation for this type of institutional separation is the increased scope for conflicts of interest and risk-taking when banks are allowed to combine lending, securities underwriting, and market-making with proprietary trading and investment on their own account.

- Banks exposed to a corporation through the lending channel may have an interest in marketing and underwriting the firm's securities to clients it may be serving in an asset management or advisory capacity. While not necessarily a problem by itself, a serious conflict of interest may arise when the said capital is raised to retire the bank's credit exposure at a time when the firm's finances are worsening.

- Legislators and regulators have emphasized — in the past and currently - the systemic risk inherent in the direct involvement of commercial banks in securities markets through proprietary trading or hedge/investment funds acquisition. ${ }^{8}$ For example, the Group of Thirty point to "unanticipated and unsustainably large losses in proprietary trading, heavy exposure to structured credit products, and ... hedge funds" as having placed the viability of other businesses of the banks and the system at large at risk. Our statistical analysis provides qualified support for an association between trading activity, returns volatility, and increasing correlation with the business cycle (Box 1). ${ }^{9}$ Moreover, it is apparent that these activities are quite distinct from the individual customer service and relationship lending that characterizes deposit management and credit intermediation.

- Capital arbitrage by banks between trading and banking books became prevalent over the decade preceding the global financial crisis. Capital charged against trading book exposures was relatively light compared to that charged against the banking book encouraging banks to place credit exposures in the trading book. As regulators have reported in the aftermath of the crisis, while trading books were earlier typically

\footnotetext{
${ }^{8}$ With reference to the U.S. Banking Act of 1933 (wherein sections 16 and 32 introduce the Glass-Steagall separation of investment and commercial banking), see the discussion in Benston (1990) and Kroszner and Rajan (1994). For the Volcker Rule (section 619 of the 2010 Dodd-Frank Wall Street Reform and Consumer Protection Act), see Group of Thirty (2009).

${ }^{9}$ The results described in Box 1 are consistent with those obtained by Stiroh and Rumble (2006) and with the assessment of relative risk in banks' different lines of business by Standard and Poor's (2011).
} 
composed of plain vanilla currency and interest rate derivatives and government bonds, the last decade saw an increasing inflow of credit derivatives and subprime securities. ${ }^{10}$

- An additional problem was that standards of disclosure and transparency for investors and creditors as applied to investment banking activity were relatively poor when compared to commercial banking at least in the U.S. The problem was exacerbated by the limited reach of financial regulation and oversight over activity in key markets, such as private label ABS and their derivatives, and the weakening of market discipline imposed by credit ratings agencies (CRAs), owing to apparent conflicts of interest and modeling gaps.

\section{Box 1. Do Trading Activities Increase the Vulnerability of Banks?}

Increasing involvement by banks in highly risky and leveraged proprietary trading activities in the lead-up to the global financial crisis has largely been seen as a key factor in generating financial distress. To ascertain if banks with a high share of total trading income ${ }^{11}$ pre-crisis were indeed the ones which experienced distress and needed official support, ${ }^{12}$ a filter rule test $^{13}$ is applied on 79 SIFIs across Europe, the U.S., and Asia. The sample includes commercial, investment and universal banks. The test on Asian banks serves as a control to gauge if the vulnerabilities to distress, as defined by the filter rule assumptions, hold for a region that remained relatively resilient during the financial crises.

\section{Filter Rule Test}

The filter rule results seem to indicate that in both Europe and the U.S., a significant majority of banks requiring assistance were institutions whose trading income-to-total revenue ratios were both in the tails of historical distribution. Similar results, however, were not observed among Asian banks. Therefore, the support for the hypothesis that banking distress during the recent global

\footnotetext{
${ }^{10}$ Financial Stability Board (2010); United Kingdom Financial Supervisory Authority (2009).

${ }^{11}$ As a majority of banks do not segregate between proprietary trading and hedging activities in trading income, we took the reported "total trading income" as an approximation for proprietary trading. Trading income in banks' financial statements comprise of revenues from revaluation of securities held in the "Trading Book," net realized gains/losses from proprietary trading activities and disposal of "Available-for-Sale" (AFS) securities and mark-to-market valuation of derivatives for "hedging." Thus, the proportion of total trading income-to-total revenue measures the degree of a bank's overall revenue source which is susceptible to market fluctuations rather than exposure from proprietary trading alone.

${ }^{12}$ Official support includes government injection, nationalization, restructuring and, in extremis, bankruptcy. Official support may not necessarily mean bankruptcy but without such support, the liquidity problem faced by the banks in question could escalate into a solvency problem which could eventually lead to bankruptcy.

${ }^{13}$ The objective of the statistical filter rule is to test the hypothesis that "banks with high shares of trading income-to-total revenue pre-crisis were most vulnerable to public bailout." The methodology includes computation of means and standard deviations (SDs) of trading income-to-total revenue ratios for the period between 1999 and 2007 with the filter rule defined as: Mean $+/-k^{*}$ SD where $k=1$ in Filter 1 and $k=2$ in Filter 2. Any bank, whose share of trading income-to-total revenue ratio in 2008 exceeds the filters as defined within its geographic sub-sample of SIFIs, is screened as 'vulnerable.' 'Vulnerable banks' are then compared with those receiving official support in 2008/2009 to gauge the predictive ability of the filter rule.
} 
financial crisis was a function of trading seems to be conditional. As such, it alludes to the need for further consideration of other factors.

Table 3. Results for U.S., European, and Asian LCFIs

\begin{tabular}{|c|c|c|c|c|c|c|}
\hline & \multicolumn{3}{|c|}{$\begin{array}{l}\text { Filter Rule } 1 \text { [No. of Banks with \% Trading } \\
\text { Income in } 2008>(\text { Mean }+1 * S D) \text { ] }\end{array}$} & \multicolumn{3}{|c|}{$\begin{array}{l}\text { Filter Rule } 2 \text { [No. of Banks with \%Trading Income } \\
\text { in } 2008>(\text { Mean }+2 * S D)]\end{array}$} \\
\hline & U.S. & $\begin{array}{c}\text { Europe } \\
\text { (including U.K) }\end{array}$ & $\begin{array}{c}\text { Asia (including } \\
\text { Australia \& Japan) }\end{array}$ & U.S. & $\begin{array}{c}\text { Europe } \\
\text { (including U.K) }\end{array}$ & $\begin{array}{c}\text { Asia (including } \\
\text { Australia \& Japan) } \\
\end{array}$ \\
\hline "Vulnerable Banks" identified by Filter Rule (A) & 6 & 25 & 8 & 5 & 21 & 3 \\
\hline No. of Banks which received Official Support in 2008/2009 (B) & 5 & 23 & 1 & 5 & 23 & 1 \\
\hline 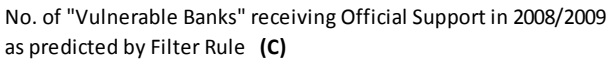 & 4 & 18 & 1 & 4 & 15 & 1 \\
\hline Predictive Ability of Filter Rule $\quad$ (C)/(A) & $66.7 \%$ & $72.0 \%$ & $12.5 \%$ & $80.0 \%$ & $71.4 \%$ & $33.3 \%$ \\
\hline $\begin{array}{l}\text { Percentage of "Vulnerable Banks" receiving Official Support } \\
\text { against total no. of banks which received Official Support } \\
\text { (C)/(B) }\end{array}$ & $80.0 \%$ & $78.3 \%$ & $100.0 \%$ & $80.0 \%$ & $65.2 \%$ & $100.0 \%$ \\
\hline
\end{tabular}

Source: Bloomberg, IMF Staff Computations

NOTE: Sample taken from 1999-2007 [US: 15 LCFls with 234 data points; Europe (including UK): 46 LCFls with 708 data points; Asia (including Australia \& Japan): 18 LCFIs with 163 data points]; SD refers to Standard Deviation

\section{Results from Filter 1}

Based on a one standard deviation (SD) assessment, 72 percent of the European SIFIs identified as 'vulnerable' required official assistance (Table 3). In the sample of U.S. banks, the corresponding matches between 'vulnerable' according to the filter rule and requiring official bank assistance was 67 percent. Thus, at first pass, the results seem to concur with the view that high exposure of revenues from trading activities increases the vulnerability of a banking institution to failure.

In Asia, the filter rule results yielded rather different outcomes with only one out of eight banks predicted by the rule receiving official support, albeit this was also the only bank which received state assistance.

\section{Results from Filter 2}

Repeating the analysis using $2 * \mathrm{SD}$ (so as to capture the effects further into the tail of distribution) confirms the above observations with little change in the predictive ability for European banks and overall improvements for U.S. and Asian banks.

Filter 2 results also confirm the significant association between trading ratios at extreme tails and the need for state assistance for U.S. and European banks during the recent crisis but in the case of Asia, only a weak association is obtained at best.

\section{Discussion}

There is conditional support regarding the importance of trading. Positive association exists between susceptibility to distress and the importance of trading income as a revenue generator for U.S. and European banks. However, similar results do not hold for Asia, with sample banks showing only a weak association at best. This could indicate a number of possible factors:

(i) Regional effects underpinned by economic fundamentals may have a role-Asian economies were more resilient during the crisis, thus underpinning the financial health of the banking systems and the systemic players therein; 
(ii) Quality of assets and earnings - low Asian exposure to toxic assets such as subprime mortgages, residential mortgage backed securities (RMBS) backed by such credits and their derivatives - may be important factors that underscore banks' resilience to stress.

Proprietary trading may be only part of the problem. Risk could emanate from losses attributed to non-proprietary trading activities such as market-making, investment banking and hedging.

The divergence of results from the sample of Asian banks also begs the question of whether the problem could be cyclical rather than structural, because Asia is in a different economic phase compared to the United States and Europe. If this is true, then prescribing a structural policy remedy such as prohibiting banks' proprietary trading altogether may lead to a suboptimal outcome when viewed through-the-cycle. In theory, controlled levels of trading with proper risk management, governance, and monitoring could promote more efficient price discovery and adds to the depth of the securities and structured products markets.

The following caveats underpinning this analysis must, in particular, be borne in mind.

- Economic Vs. Accounting Considerations. The underlying data is reported on an accounting basis rather than an economic one. This gives rise to the question of whether trading losses at a particular bank arise because of intentionally unhedged exposure (as in the case of proprietary trading) or because of non-trading exposures. For example, basis risk arising from incomplete hedging of credit or option risk undertaken in the banking book could result in trading book losses if the hedges are booked there. Alternately, losses on credit exposures booked as trading exposures in order to exploit capital arbitrage could also result in bloated trading loss figures during the crisis.

- Data Constraints. Proprietary trading is often a high frequency business. The appropriate volatility measure should be an average of daily volatility of trading income rather than annual total trading income as is the case in the filter.

The preceding discussion on the motivation for the Volcker Rule suggests at least threepossibly complementary-potential solutions.

- Imposition of higher capital requirements on commercial deposit taking banks with high levels of trading activity, where a "high level of activity" could be measured in terms of its contribution to the overall level and volatility of returns.

- Extending the perimeter of regulation and endowing supervisors with the authority to demand information from shadow banks. Giving supervisors cease-and-desist and enforcement powers on the basis of information collected from weakly supervised or unsupervised entities can also achieve the same goals as setting firm functional boundaries between commercial and investment banks.

- Imposing separation of business lines into different sets of institutions as has been attempted via the Volcker Rule in the U.S. and the United Kingdom's (U.K.) Independent Commission on Banking (ICB). 


\section{B. What Businesses Must Commercial Banks Give Up?}

The Volcker Rule - barring a number of exemptions - essentially prohibits deposit funded, licensed commercial banks in the U.S. or BHCs with U.S. banking affiliates from engaging in proprietary trading and investing or sponsoring in hedge funds and private equity funds (Figure 2 and Table 4).

The Rule has a long phase-in period for implementation. It becomes effective on the earlier of either two years after enactment of the Act (i.e., July 21, 2012), or within nine months of the issuance of accompanying regulations (due by October 21, 2011). Compliance is required from eligible institutions two years hence (so by July 21, 2014), albeit the Federal Reserve may provide up to 3 one-year extensions to institutions upon application beyond $2014 .{ }^{14}$

Figure 2. Rescoping of Banks' Businesses Under the Volcker Rule

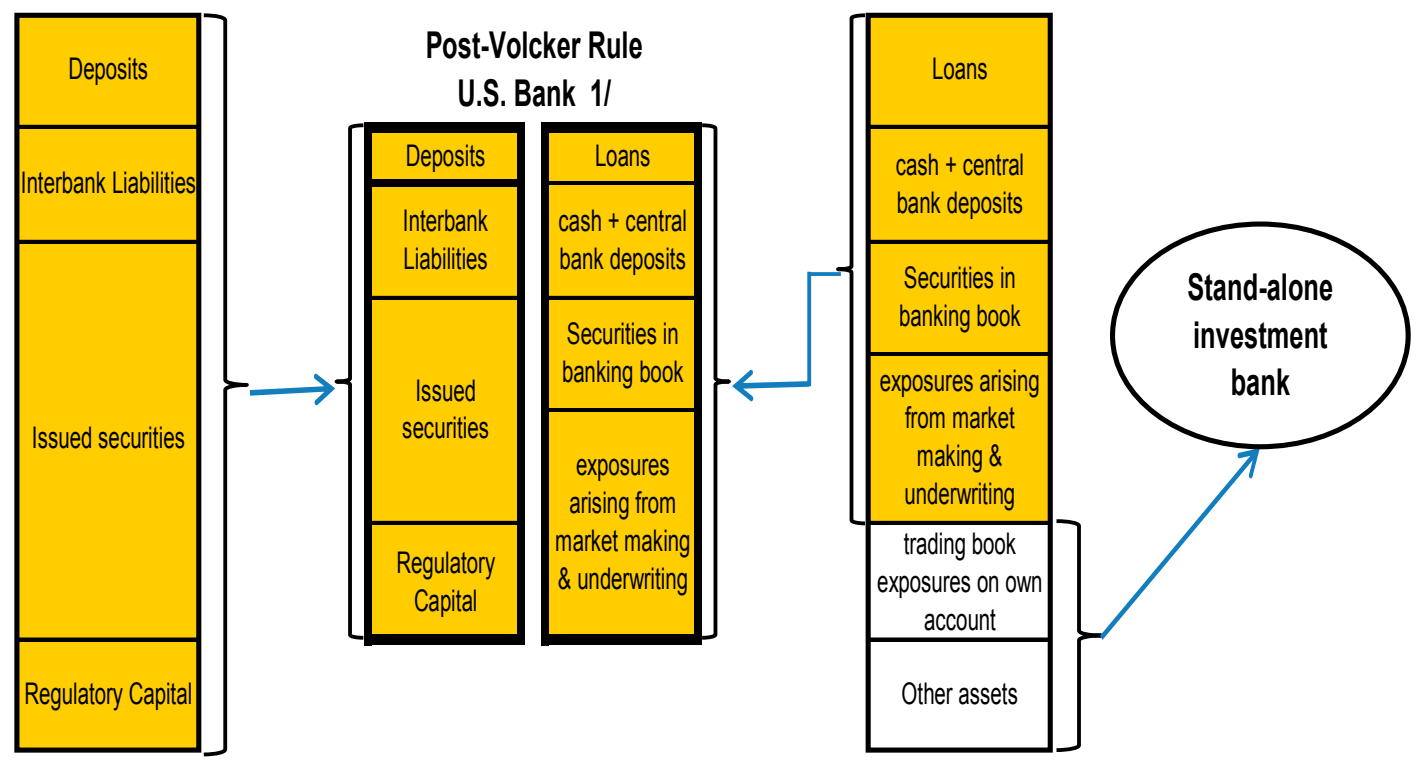

Source: Authors' summary.

Note:

1/ Besides adjustments to the balance-sheet entailed by the rule, certain activities (e.g., prime brokerage) are permitted, as is contracting with counterparties to hedge risks arising from banking business including permitted services outlined here (e.g., via derivatives markets).

\footnotetext{
${ }^{14}$ In addition, illiquid fund investments undertaken prior to May 1, 2010 are eligible for a single 5 year extension upon application to the Federal Reserve.
} 
Table 4. Volcker Rule of the Dodd-Frank Act

\begin{tabular}{|c|c|}
\hline & Proprietary Trading \\
\hline $\begin{array}{l}\text { Institutions } \\
\text { restricted from } \\
\text { engaging in the } \\
\text { business }\end{array}$ & $\begin{array}{l}\text { (i) FDIC insured depository institutions and } \\
\text { entities that own them (e.g., bank/savings-and- } \\
\text { loans/financial holding companies); } \\
\text { (ii) foreign banks / BHCs that have a U.S. bank } \\
\text { branch or subsidiary; } \\
\text { (iii) any affiliate of the foregoing institutions, } \\
\text { wherever located (i.e., institutions which share } \\
\text { at least } 25 \text { percent common control) }\end{array}$ \\
\hline $\begin{array}{l}\text { Types of } \\
\text { activities } \\
\text { prohibited } \\
\text { under the rule } \\
1 /, 2 /\end{array}$ & $\begin{array}{l}\text { Engaging as a principal (i.e., for the trading } \\
\text { account of the bank) in a transaction to buy or } \\
\text { sell any security, derivative, futures and forward } \\
\text { contracts, and any option on such securities, } \\
\text { derivatives, or contracts. }\end{array}$ \\
\hline $\begin{array}{l}\text { Exemptions } \\
\text { granted } 3 \text { I }\end{array}$ & $\begin{array}{l}\text { (i) Transactions involving bank eligible } \\
\text { securities_U.S. treasury or agency debt } \\
\text { obligations; obligations of Fannie Mae, Freddie } \\
\text { Mac, Federal Home Loan Banks, Ginnie Mae, } \\
\text { Farmer Mac, or a Farm Credit Bank; and } \\
\text { obligations of states or municipalities. } \\
\text { (ii) Transactions in connection with } \\
\text { underwriting or market making activities in } \\
\text { response to client / counterparty demand. } \\
\text { (iii) Hedge transactions } \\
\text { (iv) When acting as an agent for customers. } \\
\text { (v) Investments in small business enterprises, } \\
\text { welfare investments, and other qualified projects. } \\
\text { (v) Transactions by a regulated insurance } \\
\text { company for its general insurance account. } \\
\text { (vii) Transactions in connection with a } \\
\text { securitization or sale of loans. } \\
\text { (vii) Proprietary trading conducted by non-U.S. } \\
\text { subsidiaries or branches of non-U.S. banks } \\
\text { or financial holding companies (that may } \\
\text { have U.S. affiliates or may otherwise conduct } \\
\text { business in the U.S.) }\end{array}$ \\
\hline
\end{tabular}

Fund investments

Same as for proprietary trading.

Acquiring or retaining any equity, partnership, or other ownership interest in, or sponsoring, a hedge fund or private equity fund.

(i) The same set of exemptions as applying to proprietary trading. With regard to (viii), however, funds into which a non-U.S. affiliate of a nonU.S. bank invests cannot be offered or sold to U.S. residents; i.e., U.S. residents are, apparently, barred from investing in funds organized by major non-U.S. institutions. (ii) Funds organized and offered as part of trust, investment advisory, or fiduciary operations, subject to a number of additional conditions, including prohibitions including - participation restricted to clients of such services alone; banks' ownership / investment in the fund restricted to the lesser of 3 percent of total fund assets and 3 percent of its Tier I equity capital; no covered transactions or guarantee extensions between the bank and fund and public disclosure thereof; no ownership interest of bank staff or directors in the fund; and no related names.

Source: U.S. House of Representatives (2010).

$1 /$ Trading account is defined under the rule as an account used for acquiring or taking positions in securities and instruments listed above primarily for the purpose of selling or unwinding them in the near-future to profit for interim price movements.

2/ Sponsoring a hedge fund includes performing the following functions: (i) serving as general partner, managing member, or trustee; (ii) to select or control (or have employees, officers, directors who constitute) a majority of the directors, trustees, or managers of the fund; or (iii) to share with a fund for marketing, corporate, or promotional purposes, the same or similar name.

3/ A limited exemption is available to prime brokerage agreements between a bank serving as investment advisor or sponsor to a fund and another private equity/hedge fund in which the said fund takes an equity, partnership, or ownership interest under qualified circumstances. 


\section{The Volcker Rule vs. Glass-Steagall ${ }^{15}$}

The obvious parallel to the Volcker Rule are the Glass-Steagall restrictions placed on U.S. banking firms starting 1933 which also involved separation of commercial banking from investment banking and largely ended universal banking in the U.S. The Volcker Rule prohibits a lesser number of activities for commercial banks than Glass-Steagall did. However, the number of exemptions granted under the Volcker Rule are also significantly less than eventually offered under Glass-Steagall.

- Proprietary Trading: The set of exempt bank eligible securities is now much narrower. Prior to Gramm-Leach-Bliley, exempt securities included, for national banks, besides those mentioned in Table 4, obligations of certain foreign governments and international development banks and highly rated debt and ABS. Under the 1956 Bank Holding Companies Act, BHCs were free to engage in proprietary trading of debt and equity securities provided they did not acquire more than 5 percent of the voting rights of any issuer. And, overseas banks that had U.S. branches or subsidiaries were not subject to any such restrictions.

- Fund investing: Under Glass-Steagall, BHCs were permitted to invest in U.S. hedge and private equity funds so long as they held less than 5 percent of voting rights and less than a controlling stake in them. Under the 1978 International Banking Act and Regulation K, they were allowed to invest in foreign funds so long as they held less than 20 percent of voting rights. And, provided fund investing was carried out by non-U.S. affiliates, GlassSteagall restrictions did not apply to foreign banks.

\section{Assessment}

\section{Distinguishing proprietary trades from permissible transactions will be challenging}

Exemptions based on the intent of transactions are sensible in principle but it is difficult to find practical rules to filter out prohibited transactions.

- Given the stated motivation behind its introduction, the exemptions to the Volcker rule are often coherently built upon the economic purpose behind the transaction. For example, with regard to proprietary trading, the Rule exempts transactions related to market-making or underwriting (if in response to client demand), hedge transactions, and transactions undertaken in an agency capacity.

\footnotetext{
${ }^{15}$ Glass-Steagall restrictions are understood to mean restrictions in place prior to the passage of the U.S. Financial Modernization Act of 1999 (the so-called Gramm-Leach-Bliley Act).
} 
- Prohibiting trading undertaken explicitly via dedicated desks (so called bright line cases) is relatively straight-forward. And anticipating this, a number of U.S. BHCs have already spun-off their trading desks.

- But, identifying prohibited proprietary trading transactions dressed up as exempt hedging or market making transactions is substantially more difficult. Banks often do not hedge individual positions or transactions but deploy hedging strategies at the portfolio level. Since hedges are often incomplete, residual exposures - equity, interest rate, or optionoften put bank capital at risk. It is difficult for regulators to consistently tell apart legitimate incomplete hedges from exposures that are undertaken purposefully. Similarly, market making by banks inevitably entails putting own capital at risk for varying periods of time depending upon the liquidity of the relevant securities or derivatives.

- A study by the U.S. Financial Stability Oversight Council (FSOC, 2011) acknowledging this problem - has proposed developing suitable metrics based on granular financial information to assist supervisors in filtering prohibited transactions from exempt ones (Table 5). Moreover, recognizing the limitations of statistical approaches in carrying out this task, the FSOC has also recommended that banks adopt a programmatic regime involving regular internal audits and declarations of compliance from banks' Chief Executive Officers.

- The Financial Stability Board (FSB, 2010) raised the possibility of developing a methodology based on the U.K. Financial Services Authority's (FSA) analysis of major trading activities in London for the period 2006-2008. Based on the frequency distribution of daily trading profits, the FSA distinguished between banks with predominantly modest profits and small tails of large profits or losses and banks with large profits and losses occurring more frequently. The FSB asked whether an identification scheme sorting the first set of banks as market-makers and the rest as proprietary traders would be sensible.

- A limitation of using the results of such an analysis is that it is based on an aggregate of individual transactions and is more suited to an ex-post imposition of charges for noncompliance with the Rule's requirements rather than as an ex-ante or concurrent identification device by supervisors. In other words, it is not designed to tell apart individual market making or hedging transactions from opportunistic proprietary trades.

Purely rules-based identification methodologies may be susceptible to gaming or be too coarse, hence, entailing inefficient decision-making. Since regulation may be expected to permit securities investments made for the banking book but prohibit the same for the trading book, the burden on supervision to prevent gaming the rules will increase. In particular, mechanical holding period thresholds (e.g., minimum 30-day holding period) for eligibility to include securities markets exposures in the banking book may be susceptible to 
manipulation. On the other hand, idiosyncratic liquidity shocks or other unavoidable circumstances may precipitate un-anticipated early sale of certain securities in the buy-andhold portfolio. Rules, therefore, will need to be supplemented by discretionary supervisory judgment in order to avoid inefficient decision making.

Table 5. Quantitative Metrics Proposed by the FSOC

\begin{tabular}{|c|c|c|}
\hline Metric & Measures / Ratios & Rationale and Limitations \\
\hline $\begin{array}{l}\text { Revenue based } \\
\text { metrics }\end{array}$ & $\begin{array}{l}\text { (i) Historical revenue comparison; (ii) Revenues } \\
\text { relative to relevant industry sample; (iii) Day } 1 \\
\text { Profit \& Loss; (iv) Bid-Off Pay-to-Receive Ratio, } \\
\text { among others. }\end{array}$ & $\begin{array}{l}\text { (i) Comparative metrics use differences relative } \\
\text { to historical patterns or industry averages to } \\
\text { filter unusual patterns. } \\
\text { (ii) The idea behind first day revenues is that } \\
\text { market makers are more likely to seek } \\
\text { immediate profits by capturing the spread } \\
\text { upfront relative to trading. } \\
\text { Day } 1 \text { profit-taking when making markets is } \\
\text { a function of liquidity of the asset } \\
\text { transacted. The measure will perform worse } \\
\text { in illiquid asset markets. }\end{array}$ \\
\hline $\begin{array}{l}\text { Revenue-to-risk } \\
\text { metrics }\end{array}$ & $\begin{array}{l}\text { (i) Proportion of profitable trading days; (ii) } \\
\text { Sharpe ratios; (iii) Revenue-to-Value at Risk; } \\
\text { (iv) Value at Risk }\end{array}$ & $\begin{array}{l}\text { These measures are based on the rationale that } \\
\text { market making entails higher levels of revenue } \\
\text { per unit of risk. } \\
\text { Whether the hypothesis holds true is an } \\
\text { empirical issue. } \\
\text { FSOC acknowledges that these measures } \\
\text { would perform poorly in filtering out high } \\
\text { frequency trades or those based on non- } \\
\text { linear trading strategies. }\end{array}$ \\
\hline Inventory metrics & (i) Inventory turnover; (ii) Inventory aging & $\begin{array}{l}\text { Since returns to market making are a function of } \\
\text { inventory flow, one would anticipate that all else } \\
\text { equal these measures would be statistically } \\
\text { significantly greater than in the case of trading } \\
\text { where the gains arise from price movements of } \\
\text { assets held in the portfolio. } \\
\text { FSOC acknowledges that the measure will } \\
\text { underperform in illiquid asset markets. }\end{array}$ \\
\hline $\begin{array}{l}\text { Customer flow } \\
\text { metrics }\end{array}$ & $\begin{array}{l}\text { (i) Customer initiated trade ratio; (ii) Customer } \\
\text { initiated flow-to-inventory; (iii) Revenue-to- } \\
\text { customer initiated flow ratio }\end{array}$ & $\begin{array}{l}\text { Customer initiated transactions are more likely } \\
\text { to be the result of provision of market making or } \\
\text { hedging activity. } \\
\text { FSOC acknowledges that inter-dealer } \\
\text { transactions are a key component of market } \\
\text { making. Moreover, transactions in securities } \\
\text { markets or positions in derivatives markets } \\
\text { can be initiated by banks in order to hedge } \\
\text { the impact of specific-or group of- } \\
\text { transactions at the portfolio level. }\end{array}$ \\
\hline
\end{tabular}

Source: Financial Stability Oversight Council (2011). 


\section{Unintended costs and competitive distortions need to be guarded against}

U.S. residents can no longer be offered funds that U.S. insured depositories, BHCs and foreign banking groups invest in or sponsor. Funds can still be offered via investment banks or non-bank finance companies located in the U.S. or outside or, in the case of clients of their trust or fiduciary businesses, by banks. This narrowing of the set of eligible suppliers of investment vehicles may result in a new pricing-to-market that is disadvantageous to U.S. investors.

U.S. banks and BHCs may also be placed at a disadvantage relative to non-U.S. BHCs since the latter can continue proprietary trading or fund investing so long as it occurs outside the U.S. by non-U.S. affiliates. On the other hand, since U.S. banks and BHCs are allowed to acquire U.S. government and agency securities for their trading books but not foreign government securities, this could imply a disproportionate liquidity and capital supply impact on the market for some non-U.S. sovereign or private sector debt.

The Volcker rule will be costly to private firms for whom proprietary trading of their debt by banks has been an important factor enhancing the market liquidity of their securities and lowering their cost of capital. Such non-exempt securities include corporate bonds and private-issue ABS. Since the rule will effectively increase the liquidity risk premium applied by investors to such securities, external financing costs to non-financial firms and borrowing costs to household mortgage borrowers not qualifying for conventional conforming loans is likely to increase.

\section{Systemic risk may migrate to the shadow banking sector}

Banning proprietary trading is likely to amplify risk shifting to the shadow banking sector (which comprises hedge funds, mutual funds, and special purpose entities, among others). This would increase the accumulation of unmonitored systemic risk which could manifest itself quickly and unexpectedly during times of financial distress with spillover effects adversely affecting the real economy in the same manner as a banking crisis. In fact, the manifestation of risk may be even greater as shadow banking entities are not subject to capital adequacy frameworks, and in many areas their operations and disclosures remain opaque.

\section{FunCtional Subsidiarization: Retail Ring-FenCING}

\section{A. Why Ring-fence Retail Banking?}

An alternative way to redesign the scope of activities of banking institutions has been proposed by the ICB in the U.K. ${ }^{16}$ ICB's ring-fencing of retail operations from investment

\footnotetext{
${ }^{16}$ See the United Kingdom Independent Commission on Banking (2011a, b).
} 
banking operations does not entail full institutional separation between retail and investment banking activity, continuing to allow universal banks to avail of potential diversification benefits emanating from the integrated business model. However, the proposals place strict limits on the magnitude and the nature of the commingling of retail and investment banking operations within a single entity. In doing so, it recognizes the increased potential for contagion risk that could threaten the provision of banking services to retail depositors and small businesses that cannot afford even a temporary interruption. ${ }^{17}$

Accordingly, the objectives of the retail ring-fence are:

- To make it easier to restructure and resolve both retail and non-retail banks without extensive recourse to public funds.

- To insulate vital banking services on which households and small businesses depend from exogenous shocks.

- And, thereby, to credibly restrict the reach of public creditor guarantees to those for whom it is explicitly pre-defined.

Broadly speaking, the ICB proposals fall into two categories. First, the placement of activities either within or outside the ring-fence (the location of the fence). Second, and within the broader business group structure, the placement of restrictions on financial interconnections between the ring-fenced and non-ring-fenced entities (the height of the fence). This is achieved by the placement of ceilings on, and risk-based pricing of, intragroup transactions and by specifying minimum capital standards for the ring-fenced banks. ${ }^{18}$

\section{B. Implementation}

\section{What ring-fenced banks must do, can do ... and what they cannot do}

As a first step, implementation requires the identification of banking activities that are to be ring-fenced. Equally important is determining the type of separation applying to a given business line. In its report (2011b), the ICB has proposed distinguishing between the following four types of activities.

\footnotetext{
${ }^{17}$ Temporary interruptions would, when occurring in an environment of increasing macro-financial distress, threaten systemic stability via confidence effects and via the knock-on impact on the payments system, besides causing direct loss of welfare.

${ }^{18}$ This would be in addition to U.K. banks' wholesale and investment banking activities remaining subject to capital standards agreed internationally.
} 
- Services that must be offered within the ring-fence. These include retail deposits and the provision of over-drafts to individuals and small and medium-sized enterprises. Private banking customers are not included among the set of such individuals given that they are likely to have a wider set of options to meet their banking needs.

- Activities that are permitted within the ring-fence. These include, besides the mandatory ones described above, all non-prohibited services such as consumer and SME loans, mortgages, credit cards, corporate lending, leasing and factoring, and wealth management advisory services, among others. The ICB does not place restrictions on the mode and mix of on-balance sheet instruments that ring-fenced banks may use for funding their businesses so long as these do not result in the assumption of market risk by the firm. ${ }^{19}$

- Activities that are excluded from the ring-fence. These include services provided outside the European Economic Area (EEA); transactions with non-ring-fenced financial firms that are not affiliates of the ring-fenced bank (with the exception of regulator approved payments services transactions); services that would result in either a trading book asset or in the requirement to hold capital against market and counterparty credit risks; and services relating to secondary market activity such as the purchase of loans or securities. These prohibitions preclude ring-fenced banks from engaging in securities under-writing, market making, mergers and acquisition advisory services, loans and ABS warehousing, and sponsoring securitization deals.

- Activities necessary to support permitted services may also be performed. Ringfenced banks' permitted business operations entail assumption of credit, market, and liquidity risk which they would need to hedge. Accordingly, it is reasonable to expect ring-fenced banks to engage in derivatives contracts with non-ring fenced banks which would entail assumption of market and counterparty credit risks. Ring-fenced banks must also undertake investment in assets that are liquid by virtue of either an active secondary market or by them being eligible for repurchase by the central bank. However, the proposals exclude contracting with counterparties outside of the ring-fenced banks' own financial group that are offering prohibited services. It would appear, therefore, that risks must be managed, possibly in a synthetic fashion, by combining intra-group contracting with the sale and purchase of marketable securities and their derivatives.

\section{Shielding ring-fenced banks from contagion}

Whereas the retail ring-fence proposal allows universal banking groups to continue maintenance of ring-fenced and other businesses under one roof, it mandates that measures

\footnotetext{
${ }^{19}$ Such as would result, for example, if the combined funding mix and asset allocation of the ring-fenced bank exposes it to losses emanating from interest rate fluctuations or currency rate movements.
} 
be put in place to protect the ring-fence from contagion risk. This has the following implications for the legal corporate structure of such groups and for the economic linkages between their ring-fenced and non-ring-fenced affiliates.

\section{Ring-fenced banks are to be set up as separate legal entities within their financial} groups. In a branch-based structure, monitoring compliance with prudential rules related to capital, liquidity, and intra-group exposures applied on a solo basis to the ring-fence could be prohibitively difficult. Moreover, in order to ensure that ring-fenced operations can be spunoff in a group-wide restructuring or resolution, a number of other criteria must be satisfied. Arrangements whereby the ring-fenced bank continues to have access to all operations, staff, data, and services essential to its operations are necessary. For example, a ring-fenced bank ought to be a member of relevant payments systems or should have, as its agents, other ringfenced banks. In terms of group organization, ring-fenced banks cannot (partially) own affiliates that offer services prohibited within the ring-fence.

Subsidiarization should be functional and not merely legal and operational. This entails three important considerations.

- Ring-fenced banks must have operationally independent management and board. Without this, continuity of business operations when the rest of the group is in distress or under resolution may be difficult to ensure. Boards are expected to strive to maintain the integrity of the ring-fence, albeit the compliance protocols under the Volcker Rule are not imposed by the ICB.

- Ring-fenced banks must be independently and separately capitalized reflecting minimum regulatory standards assessed on a solo basis. The ICB recommends applying solo equity and leverage standards to the ring-fenced subsidiary (Table 6). There are no limits on the transfer of capital and liquidity from a financial group's nonring-fenced affiliates into the ring-fence, but the scope for transfers in the opposite direction, including of dividend payments, is explicitly constrained.

- Restrictions on intra-group transactions. The ICB proposals place no restrictions, beyond those already embedded in the prudential framework for banks, on intra-group exposures between ring-fenced affiliates. Turning to financial interconnections with nonring-fenced affiliates, their focus is on ensuring appropriate risk pricing of such transactions instead of placement of tougher quantitative limits thereon. Accordingly, such transactions should necessarily be on a third-party basis and conducted on a commercial basis at market prices or imputed fair values (Figure 3). ${ }^{20}$

\footnotetext{
${ }^{20}$ Large/single exposure counterparty limits applicable to third party transactions also apply to intra-group transactions.
} 
Table 6. Prudential Capital Constraints Applying to Ring-fenced Banks

\begin{tabular}{|c|c|c|c|c|}
\hline Size & Equity & Leverage ratio & $\begin{array}{l}\text { Primary loss } \\
\text { absorbing } \\
\text { capacity }\end{array}$ & Comments \\
\hline All ring-fenced banks & & Tier I > 3 percent & & $\begin{array}{l}\text { In a resolution, } \\
\text { insured } \\
\text { depositors rank } \\
\text { ahead of all } \\
\text { unsecured } \\
\text { creditors }\end{array}$ \\
\hline $\begin{array}{l}\text { RWA between 1-to-3 } \\
\text { percent of U.K. GDP }\end{array}$ & $\begin{array}{l}\text { Sliding scale for } \\
\text { minimum equity- } \\
\text { to-RWA of } \\
\text { between } 7 \text {-to-10 } \\
\text { percent }\end{array}$ & $\begin{array}{l}\text { Sliding scale for } \\
\text { minimum leverage } \\
\text { ratio of between 3- } \\
\text { to-4.06 percent }\end{array}$ & $\begin{array}{l}\text { Sliding scale for } \\
\text { minimum capital } \\
+ \text { bail-in bonds of } \\
\text { between } 10.5 \text {-to- } \\
17 \text { percent of } \\
\text { RWA }\end{array}$ & $\begin{array}{l}\text { Supervisor has } \\
\text { discretion to } \\
\text { increase primary } \\
\text { loss absorbing } \\
\text { capacity by up to } \\
3 \text { percentage } \\
\text { points }\end{array}$ \\
\hline $\begin{array}{l}\text { RWA of more than } 3 \\
\text { percent of U.K. GDP }\end{array}$ & $\begin{array}{l}\text { Minimum equity- } \\
\text { to-RWA of } 10 \\
\text { percent }\end{array}$ & $\begin{array}{l}\text { Minimum leverage } \\
\text { ratio of } 4.06 \\
\text { percent }\end{array}$ & $\begin{array}{l}\text { Capital and bail-in- } \\
\text { bonds should be } \\
\text { at least } 17 \\
\text { percent of RWA }\end{array}$ & $\begin{array}{l}\text { Supervisor has } \\
\text { discretion to } \\
\text { increase primary } \\
\text { loss absorbing } \\
\text { capacity by up to } \\
3 \text { percentage } \\
\text { points }\end{array}$ \\
\hline
\end{tabular}

:Source: United Kingdom Independent Commission on Banking (2011b). 
Figure 3. Rescoping of Bank's Businesses Under the ICB Ring-fence

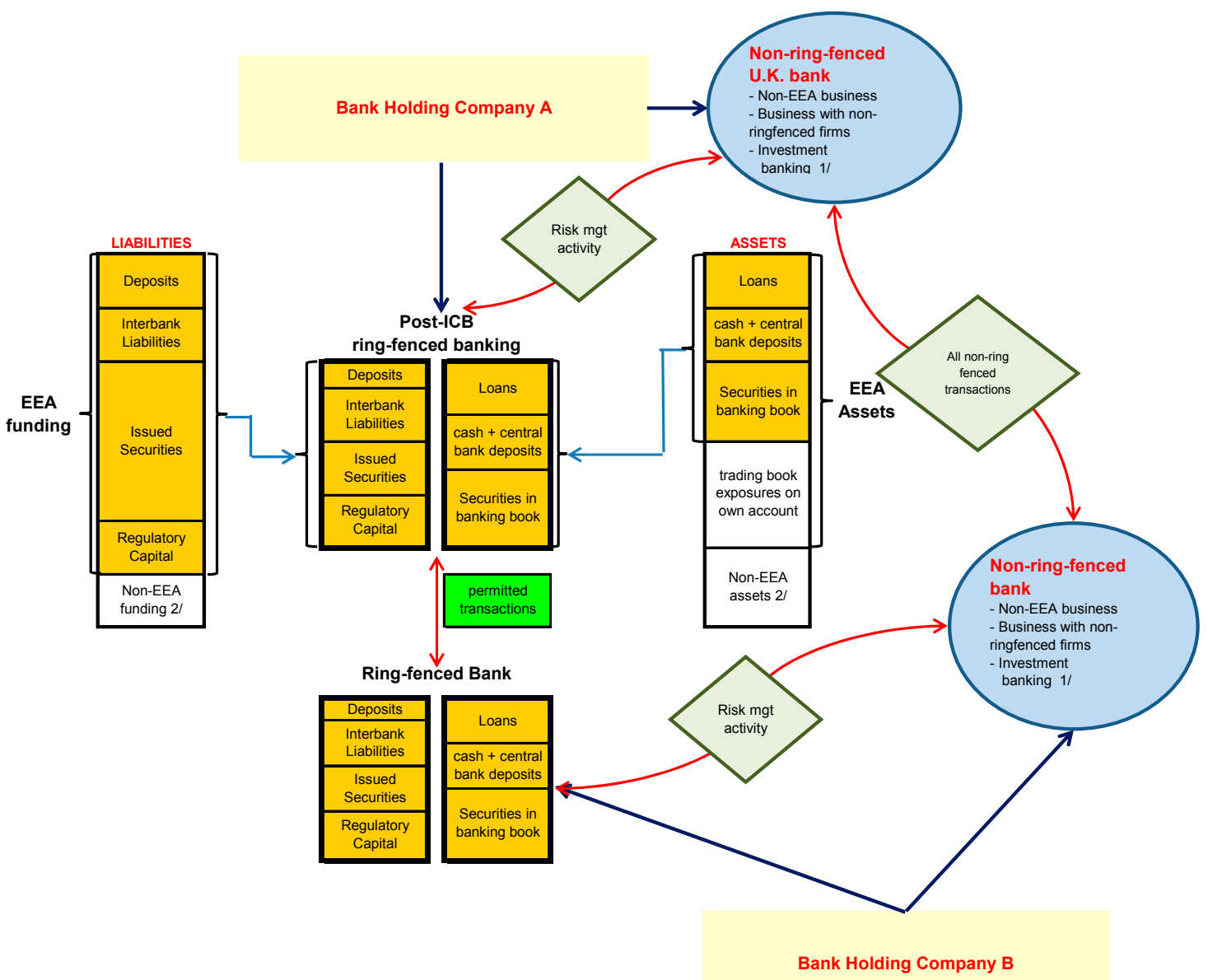

Source: Authors' summary.

Note:

1/ Understood to include proprietary trading, securitization deal sponsorships and services such as underwriting, market making, prime brokerage services, and loan/securities warehousing, among others.

2/ Funding raised from/exposures to non-EEA clients and funding raised/exposures through non-EEA affiliates.

\section{Assessment}

Diversification benefits entailed by universal banking are preserved under the proposals, albeit potentially with limitations. Ring-fenced banks can, when necessary, continue to benefit from capital and liquidity surpluses elsewhere in the group and can, to a limited degree, extend this benefit to affiliates. Limits on the ability to do the latter also protect retail operations from contagion, more credibly restrict the penumbra of public creditor guarantees to retail creditors, and ensure continuity of that part of the firm in a crisis.

Subsidiarization - in the legal, operational, and functional senses - is necessary for the proposals to succeed in achieving their goals. However, the practical achievement of this 
remains challenging despite the final report adding substantial additional operational guidance relative to the interim April report (ICB, 2011a).

- Risk management and intra-group exposures. Since exposures to non-ring-fenced banks or finance companies outside of their own financial group are prohibited, risk management and hedging within the ring-fence may have to exclusively rely on contracting within the group ${ }^{21}$. So long as arms-length contracting is in place, there appear to be no further constraints - besides regulatory limits on intra-group or singleparty exposures - on ring-fenced banks transacting with group affiliates to hedge risk. In order for subsidiarization to ensure isolation and continuity of the ring-fenced operations, however, prudential rules and oversight will need to ensure that back-up arrangements that survive distress or failure of the wider group are in place for the ring-fenced bank to avail of. Moreover, in the case of some types of transactions, such as master netting in repurchase agreements, this will require first arranging the transfer of existing contracts, and subsequently, the maintenance of separate contracts with clients, payments and settlement systems, and risk management counterparties. This could entail, besides significant adjustment costs, a permanent increase in the cost of provision of banking services. Intensification of supervision to ensure institutional compliance may be expected and will imply a similar increase in implementation costs for prudential authorities.

- Filtering prohibited from permissible transactions will be as challenging under the ring-fence as under the Volcker Rule. The location of the ICB ring-fence is more restrictive than the Volcker Rule (Table 7). However, ring-fenced institutions must maintain (i.e., buy, hold, and sell) a portfolio of securities, engage in secured lending transactions and be counterparties to derivatives contracts. Like the Volcker Rule, ringfenced institutions can engage in these only to support permitted services and transactions, but, the same identification and implementation challenges described earlier will also arise for U.K. ring-fenced banks. Whether the additional prohibitions on marketmaking, underwriting and sponsorship of securitization deals make this hurdle less costly to surmount under the ICB proposals remains to be seen.

\section{- Reconciling limits on market and counterparty risks with limits on intra-group} contagion may be challenging. Ring-fenced banks' need to hedge financial risks necessitates exposures to financial markets and counterparties which must be from within their own financial groups. This increases the risk of raising intra-group exposures across the ring-fence to beyond a desirable level from the perspective of spinning off the ringfenced business and maintaining business continuity when the need arises.

\footnotetext{
${ }^{21}$ Indeed, this raises the important question of how stand-alone retail banks can hedge their risks. The compliance and supervision costs associated with ensuring that market products purchased by such firms to hedge risk are not targeted at exposing own-capital to market or counterparty credit risk could be quite high.
} 
Table 7. Comparing the Volcker Rule and the ICB Proposals

Criteria
Applies to
Activities that must be
performed by banks to
whom rule applies $1 /$

Prohibited activities

Legal corporate structure

Permitted economic links with entities offering prohibited services
Volcker Rule

All U.S. banks and bank-holding companies and all foreign bank holding companies with U.S. subsidiaries or branches

No activities are mandatory, but would typically include deposit taking, credit intermediation, and often-though-notalways, brokerage services, market making and underwriting

Proprietary trading and funds investing, a sub-set of investment banking activities

Banks or holding companies subject to the rule cannot house affiliates, even as separately capitalized and independent subsidiaries, that engage in prohibited activities

No explicit constraints specified, albeit no such links can be established that seek to circumvent prohibition of proprietary trading and funds investing
ICB ring-fence

All U.K. banks and bank holding companies that engage in services that mandatorily belong to the ringfence plus U.K. subsidiaries of foreign $\mathrm{BHCs}$ offering ring-fenced services.

Deposit taking and lending and payments services to individuals and small and medium-sized businesses
Trading, market-making, and securities underwriting; services resulting in trading book exposures or holding of regulatory capital against market and counterparty credit risks; and services offered outside the EEA

Ring-fenced banks can co-exist within the same group as affiliates offering prohibited services. But, they must do so as separately capitalized, independently managed subsidiaries.

No such links can be established without prior regulatory approval except with such entities within a ringfenced bank's own group. Within group, such transactions must be conducted at arms-length and be subject to prudential constraints on intra-group exposures.

Sources: FSOC (2011); U.S. House of Representatives (2010); and U.K. ICB (2011b)

Note:

1/ Since offering retail banking services requires a banking license, such activities are necessarily ring-fenced under the Volcker Rule. 
Organization of global retail banking. If a U.K. banking group has retail operations in other jurisdictions, the ICB proposals do not compel the group to ring-fence such businesses. This could be the case, however, if the group preferred a corporate structure wherein retail businesses were organized in a separate subsidiary. An interesting question is, whether retail operations ought to be organized in a separately capitalized subsidiary with independent management, and if so, should such subsidiarization be organized along national boundaries. One argument supporting affirmative answers to these questions is that retail banking is likely to be geographically separate and independent, whereby enforcement of ring-fencing of a global bank's retail operations can be performed by national prudential authorities. ${ }^{22}$ From the authorities' perspectives, a clear advantage of adopting this form of organization is that the benefits ensuing from tax payer cost outlay to ensure continuity of the business would be ring-fenced for the benefit of retail customers of the domestic subsidiary.

\section{Policy Implications}

The three proposals described in this paper provide alternative road-maps for the transition of SIFI business models from universal banking towards separate provision of deposit-taking, lending, and payments functions on the one hand, and investment or wholesale banking on the other. While the proposals share a number of common elements, there are important differences there-between. A summary comparison is presented in Figure 4. We define two separate dimensions in which banks' businesses will be constrained, the number of prohibited services, and the degree of interaction permitted with providers of such services, and compare the relative constraints imposed by the proposals under each of these dimensions. For example, while the ICB proposes to prohibit more activities than the Volcker Rule (and less so than utility banking), it permits greater intra-group transactions/ exposure to non-ring-fenced affiliates.

\section{Redesigning the business models of SIFIs will not work without complementary measures to strengthen the prudential framework. Restrictions on proprietary trading and risky lending are tools that are largely complementary to strengthened regulation, more intensive oversight, and more effective recovery and resolution frameworks, all of which are targeted at mitigating the TITF problem. ${ }^{23}$}

\footnotetext{
${ }^{22}$ Fiechter et. al. (2011) notes, in fact, that the subsidiary structure may work well for retail banks, as it may benefit from a local management team that is fully accountable for the performance of an affiliate focused on local retail operations. On the other hand, the subsidiary structure may be less suitable for universal and investment banking activities because it could constrain their ability to manage liquidity globally and to serve large corporate clients. Large Spanish banks with a retail focus, as well as the U.K. global bank HSBC, largely operate with a subsidiary-based structure.

${ }^{23}$ For example, the implementation of living wills is facilitated by both measures since they would result in simpler, less interconnected organizations and businesses. This facilitates design of effective recovery and resolution plans.
} 
Figure 4. Comparing the Proposals: A Summary

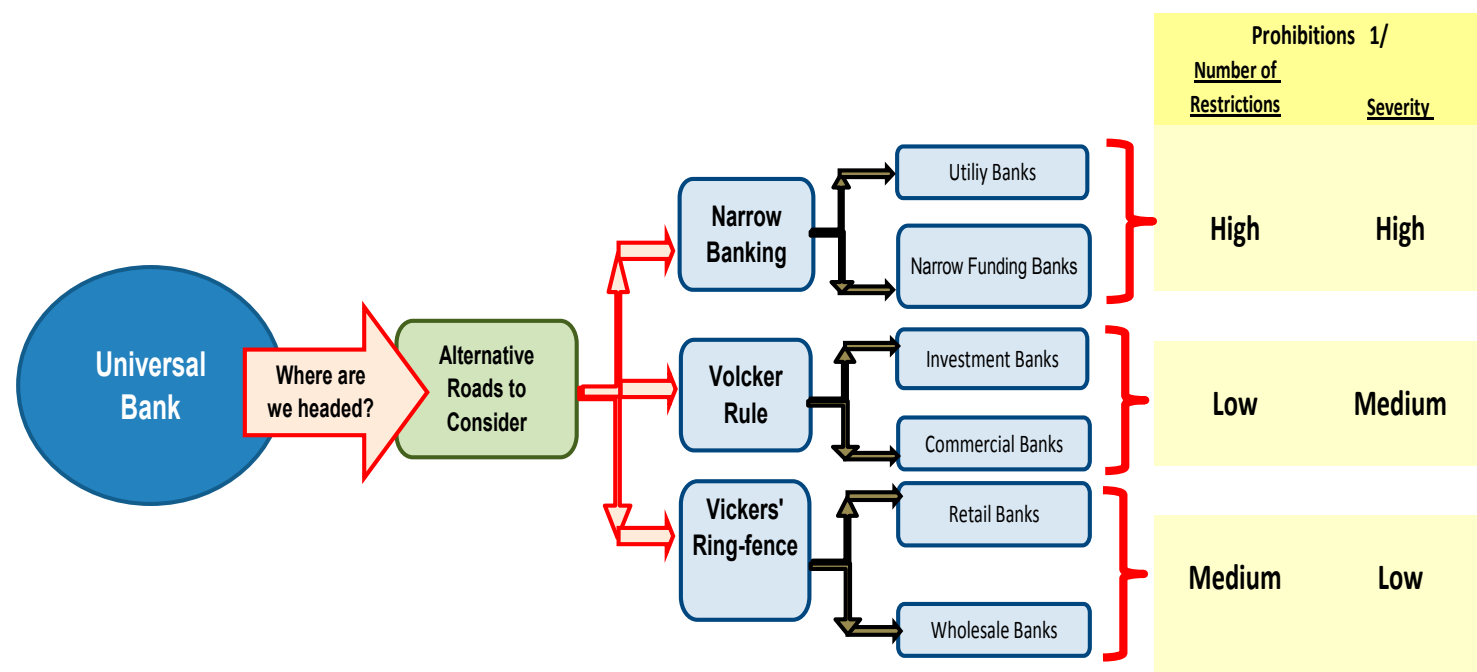

Note:

1/ Rankings for each proposal are relative to other proposals. "Number of restrictions" corresponds to number of prohibited activities; "severity" refers to potential for within-group transactions/interconnections to firms engaging in prohibited activities.

Enhancing oversight of the shadow banking sector is essential to prevent migration of systemic risk in response to tighter constraints on regulated banks' business models.

The proposals discussed in this paper will be limited in their ability to reduce systemic risk if corresponding reforms are not made with respect to the shadow banking sector. Whilst regulated banks may be on safer grounds, the shift in excessive risk-taking incentives towards the unregulated parts of the financial system could render quasi-banks susceptible to distress. To the extent that these institutions become systemic and maintain links with regulated banking institutions, systemic risk will continue to exist. Thus, any policy framework aimed at addressing the issue of systemic risk should encompass the shadow banking system. In addition, prudential supervision may need to be extended to this sector to improve the transparency and disclosure of information, to capture the activities of special purpose vehicles and their linkages, as well as the stakeholders involved.

\section{The loss of any diversification benefits could represent a significant cost and careful} assessment is required in selecting a rescoping model that will limit this loss. Reduction in diversification benefits due to the separation of investment from commercial banking may be a significant cost that may not be balanced by gains if - as a result — risky activities move to the shadow banking system. In our view, this applies more to the narrow banking and Volcker rule proposals than to retail ring-fencing since the latter would still permit preservation of diversification gains and risk taking, albeit to a limited degree within a universal bank combining retail and wholesale businesses. 
Operational challenges specific to each proposal may limit their effectiveness, implying that they be introduced in combination with some of the other tools assessed in this paper. Specifically:

- Separation of utility and non-utility banking - necessary to the success of narrow banking - may be prohibitively difficult to achieve in practice with important utility components leaking out to the shadow banking system which ultimately defeats the raison d'être of the proposal.

- For this reason, efforts to extend the perimeter of regulation and oversight remain vitally important.

- Since identification and separation of proprietary trading transactions from hedging or market making transactions will be difficult in practice, reliance on higher capital surcharges — overall and on the trading book — will be important complementary measures.

- Structural measures to limit the scope of SIFI activities - while providing a direct way of dealing with the TITF problem, have not gained international support, and hence could be difficult to implement and adopt on a globally consistent basis. Harmonization of the regulatory tool-kit in countries housing TITF activities will be important to avoid competitive distortions and arbitrage opportunities. As a corollary, and given their role as global financial centers, careful assessment of the opportunities for regulatory arbitrage potentially generated by differences between the Volcker rule and the ICB ring-fence and their implementing regulations will be warranted.

- Riskier activities can also be limited through other prudential measures that are in-train, such as higher risk weights on trading and securitization under Basel or buffering common equity with contingent capital instruments which has the additional potential advantage of sharpening investor incentives for monitoring bank management. Ultimately however, success will be predicated upon improved governance frameworks and strong supervision. 


\section{REFERENCES}

Basel Committee on Banking Supervision, (2010), The Joint Forum Review of the Differentiated Nature and Scope of Financial Regulation, (January), Basel: Bank for International Settlements.

Benston, G., (1990), The Separation of Commercial and Investment Banking, Oxford, U.K.: Oxford University Press.

Bryan, L., (1991), “Core Banking”, McKinsey Quarterly.

Fiechter, J., I. Ötker-Robe, A. Ilyina, M. Hsu, A. Santos, and J. Surti (2011), "Subsidiaries or Branches: Does One Size Fit All”, Staff Discussion Note 11/4, Washington, D.C.: International Monetary Fund.

Financial Stability Board, (2010), "Constraints on Business Activity", Standing Committee on Regulation and Supervisory Coordination, (May 12), Basel.

Financial Stability Oversight Council, (2011), Study and Recommendations on Prohibitions on Proprietary Trading and Certain Relationships with Hedge Funds and Private Equity Funds, (January 19), Washington, D.C., Available at http://www.treasury.gov/initiatives/Pages/FSOC-index.aspx

Gorton, G. and A. Metrick, (2010), "Regulating the Shadow Banking System", Brookings Papers on Economic Activity 2, (Fall), pp. 26-312.

Group of Thirty (2009), Financial Reform: A Framework for Financial Stability, (January), Washington D.C., Available at http://www.group30.org/pubs/reformreport.pdf

Kashyap, A., R. Rajan and J. Stein, (2002), "Banks as Liquidity Providers: An Explanation for the Coexistence of Lending and Deposit-Taking," Journal of Finance, Vol. 57, pp. 3373.

Kay, J., (2009), "Narrow Banking: The Reform of Banking Regulation”, unpublished, Available at http://www.johnkay.com/wp-content/uploads/2009/12/JK-Narrow-Banking.pdf

Kroszner, R. and R. Rajan, (1994), "Is the Glass-Steagall Act Justified? A Study of the U.S. Experience with Universal Banking Before 1933," American Economic Review, Vol. 84, pp. 810-32.

Litan, R. (1987), What Should Banks Do? Washington, D.C.: The Brookings Institution.

Ötker-Robe, I., A. Narain, A. Ilyina, and J. Surti, (2011), “The Too Important to Fail Conundrum: Impossible to Ignore and Difficult to Resolve," Staff Discussion Note 11/12, Washington, D.C., International Monetary Fund.

Pierce, J., (1991), The Future of Banking, New Haven, CT: Yale University Press. 
Pozsar, Z., T. Adrian, A. Ashcraft, and H. Boesky, (2010), "Shadow Banking", Staff Report 458, New York, N.Y.: Federal Reserve Bank of New York.

Standard and Poor's, (2011), "Industry Risk for Investment Banking is Generally Higher than for Other Financial Institutions," January 6.

Stiroh, K. and A. Rumble, (2006), "The Dark Side of Diversification: The Case of U.S. Financial Holding Companies," Journal of Banking and Finance, Vol. 30, pp. 2131-61.

United Kingdom Financial Services Authority, (2009), The Turner Review: A Regulatory Response to the Global Financial Crisis, (March), London, U.K.

United Kingdom Independent Commission on Banking, (2011a), Interim Report: Consultation on Reform Options, (April), London, U.K. (2011b), Final Report Recommendations, (September), London, U.K.

United States House of Representatives, (2010), The Dodd-Frank Wall Street Reform and Consumer Protection Act, H.R. Bill No. 4173, (July 21), $111^{\text {th }}$ Congress of the United States. 